$\underline{\text { Article }}$

\title{
Cobalt(II) Phthalocyanine Bonded to 3-n-propylimidazole Immobilized on Silica Gel Surface: Preparation and Electrochemical Properties
}

\author{
Sergio T. Fujiwara, and Yoshitaka Gushikem* \\ Instituto de Química, Unicamp, C.P. 6154, 13083-970 Campinas - SP, Brazil
}

\begin{abstract}
A ftalocianina de cobalto(II) imobilizada sobre a sílica gel (área superficial SBET $=500 \mathrm{~m}^{2} \mathrm{~g}^{-1}$ ) modificada com 3-n-propilimidazol, foi incorporada a um eletrodo de pasta de carbono e mostrou-se eficiente na eletrocatálise da oxidação do ácido oxálico. As interações intermoleculares do complexo, as quais podem normalmente interferir no processo redox, praticamente não foram observadas no presente caso, devido a baixa densidade média do complexo na superfície do material sintetizado $\delta=4,7 \times 10^{-13} \mathrm{~mol} \mathrm{~cm}^{-2}(\delta=\mathrm{Nf} / \mathrm{SBET}$, onde Nf é a quantidade de Co-Ftalocianina adsorvida por grama de silica gel modificada ). A resposta linear do eletrodo para concentrações do ácido oxálico entre $6,5 \times 10^{-4}$ e $3,2 \times 10^{-3} \mathrm{~mol} \mathrm{~L}^{-1}$, associado com sua alta estabilidade química tornam o material com a ftalocianina de cobalto(II) ligado covalentemente muito atrativo na preparação de uma nova classe de sensores químicos.
\end{abstract}

Co-Phthalocyanine complex was immobilized on 3-n-propylimidazole groups grafted on a porous $\mathrm{SiO}_{2}$ surface (specific surface area $\mathrm{S} B E T=500 \mathrm{~m}^{2} \mathrm{~g}^{-1}$ ) and efficiently electrocatalyzed the oxalic acid oxidation on a carbon paste electrode surface made of this material. Intermolecular interactions of the complex species which can normally interfere in the redox process practically are not observed in the present case because of a low average surface density, $\delta=4.7 \times 10^{-13} \mathrm{~mol}$ $\mathrm{cm}^{-2}(\delta=\mathrm{Nf} / \mathrm{S} \mathrm{BET}$, where $\mathrm{Nf}$ is the amount of adsorbed Co-phtalocyanine per gram of modified silica gel) of the complex species material prepared. The linear response of the electrode to oxalic acid concentration, between $6.5 \times 10^{-4}$ and $3.2 \times 10^{-3} \mathrm{~mol} \mathrm{~L}^{-1}$, associated with its high chemical stability makes the covalently immobilized Co-phtalocyanine complex material very attractive in preparing a new class of chemical sensors.

Keywords: cobalt phthalocyanine, silica gel, 3-n-propylimidazole silica gel, oxalic acid electroxidation, immobilized cobalt phthalocyanine complex

\section{Introduction}

Phthalocyanine metal complexes have been known for a long time as homogeneous and heterogeneous catalysts for a great variety of chemical reactions ${ }^{1-3}$ where the metal of the macrocyclic complex acts as a redox center. Therefore, it is very interesting that more applications for metallated phthalocyanines could be found. It is possible to extend many applications in solution phase of these complexes to a solid phase by an immobilization process on an inert matrix surface and by an impregnation or chemical bonding procedures ${ }^{4}$. Complexes immobilized by an impregnation procedure on an inert matrix surface have been used to prepare chemically modified electrodes viewing numerous electrocatalytic reaction $5^{5-12}$. Another procedure has been to immobilize the phthalocyanine or porphyrine complexes by a chemical bonding of the central metal atoms to basic groups grafted on solid surfaces ${ }^{13-21}$.

This work reports the electrochemical properties of the Co-phthalocyanine complex bonded to imidazole groups grafted on a porous silica gel surface. The main objectives were: (a) to obtain a highly dispersed covalently bonded macrocyclic complex and (b) to study a model catalytic reaction in order to have a better understanding of the mechanism of electron transfer process on a surface of an insulating material. Electroxidation of oxalic acid was studied in order to probe the potentiality of the material. 


\section{Experimental}

\section{Preparation of the chemically modified silica}

Preparation of the material was carried out in two steps. In the first step, $3.4 \mathrm{~g}(53 \mathrm{mmol})$ of imidazole and $9.2 \mathrm{~cm}^{3}$ (50 mmol) of 3-chloropropyltrimethoxysilane from Aldrich were added into a reaction flask containing 250 $\mathrm{cm}^{3}$ of dry toluene, and the mixture was refluxed for $2 \mathrm{~h}$ under nitrogen atmosphere. In the second step, $20 \mathrm{~g}$ of silica gel with specific surface area of $500 \mathrm{~m}^{2} \mathrm{~g}^{-1}$ and previously degassed under vacuum $\left(10^{-4}\right.$ Torr $)$ at $393 \mathrm{~K}$ was immersed in a flask containing this mixture. The mixture was refluxed for more $8 \mathrm{~h}$ under nitrogen atmosphere. The resulting material was filtered, washed with toluene and ethanol. Furthermore, the solid was washed with $10^{-3} \mathrm{M}$ aqueous $\mathrm{HCl}$ solution, $0.5 \mathrm{wt} \% \mathrm{HCO}_{3}^{-}$solution and finally with bidistilled water. The solid was dried under vacuum $\left(10^{-4}\right.$ Torr) at $393 \mathrm{~K}$.

The CP MAS NMR of ${ }^{29} \mathrm{Si}$ showed the following $\mathrm{Si}$ peaks of interest (bold character): $\mathrm{RSi}(\mathrm{OSi} \equiv)_{3},-67 \mathrm{ppm}$, and $\mathrm{RSi}\left(\mathrm{OCH}_{3}\right)(\mathrm{OSi} \equiv)_{2}-58 \mathrm{ppm}$, where $\mathrm{R}$ is the $\mathrm{n}$ propylimidazole radical. According to this result, Figs. 1a-c describe the reaction equations.

\section{Adsorption of $\mathrm{Co}(\mathrm{II})$ phthalocyanine on}

3-n-propylimidazole silica gel

Cobalt(II) phthalocyanine, CoPc, $(0.015 \mathrm{~g} ; 26 \mu \mathrm{mol})$ was dissolved in dimethylformamide and $1 \mathrm{~g}$ of the 3-npropylimidazole silica gel, hereafter designated as SiIm,

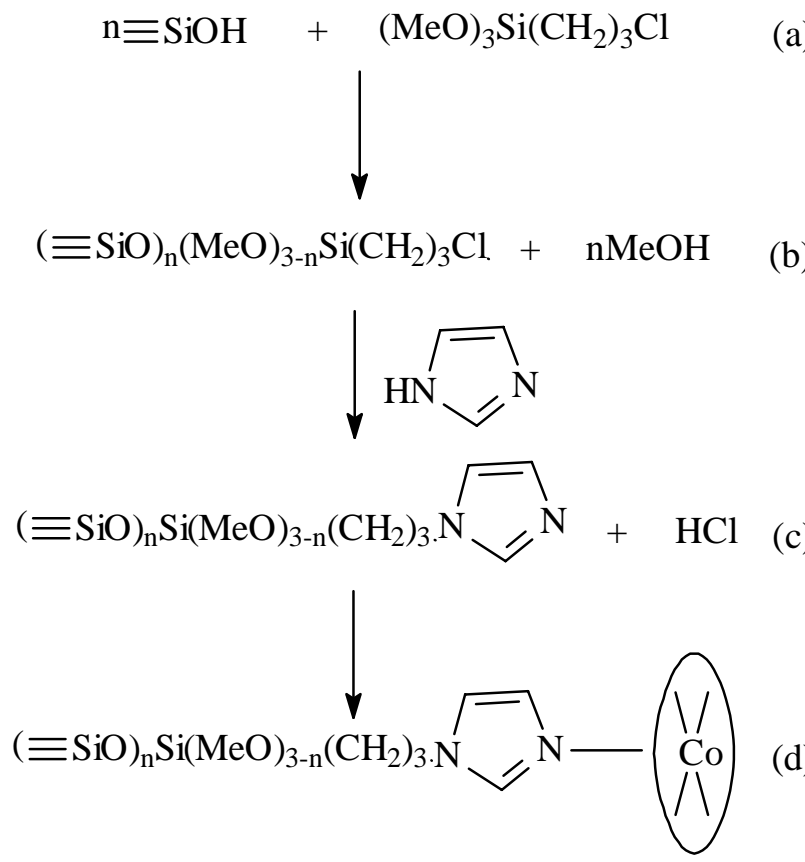

Figure 1. Scheme of 3-n-propylimidazole silica gel preparation and CoPc adsorption. was immersed in this solution, stirred and allowed to stand for $24 \mathrm{~h}$. The solid was filtered and washed exhaustively with ethanol until a clear filtrate was obtained. Figure 1d shows the immobilized CoPc on SiIm.

\section{Chemical analyses}

The solid was treated with concentrate $\mathrm{HNO}_{3}$ solution and heated until evaporation of the acid to dryness. Then the metal ion was extracted with $0.1 \mathrm{M} \mathrm{HNO}_{3}$ solution and analyzed by atomic absorption spectrometry. The amount of adsorbed $\mathrm{Co}$ (II) phthalocyanine was $2.2 \mu \mathrm{mol} \mathrm{g}{ }^{-1}$.

The amount of the immobilized organic functional groups was determined on basis of the $\mathrm{N}$ elemental analysis. The analytical results gave $0.73 \mathrm{wt} \%$ of nitrogen corresponding to $0.26 \mathrm{mmol} \mathrm{g}^{-1}$ of the attached functional groups.

\section{Measurements}

The electronic absorption spectra of the solid samples were obtained immersing the material in carbon tetrachloride using a quartz cell with $1 \mathrm{~mm}$ path length. The equipment used was a Beckman DU 640 spectrophotometer.

The electrochemical measurements were made with an electrode prepared by mixing graphite (Fluka), $50 \mathrm{wt} \%$, and $\mathrm{SiIm} / \mathrm{CoPc}, 50 \mathrm{wt} \%$, and a mineral oil as a binder. This electrode was used as the working electrode, the reference was the saturated calomel electrode, SCE, and a platinum wire was used as the counter electrode. All measurements were made in a electrochemical cell under nitrogen atmosphere. The equipment used was the potentiostat/galvanostat PAR 273 A, from EG\&G.

\section{Results and Discussion}

\section{Electronic absorption spectra}

Figure $2 \mathrm{a}$ shows the electronic absorption spectrum of the solid SiIm/CoPc, obtained by immersing the solid in carbon tetrachloride. Scattering of the radiation is not ob-

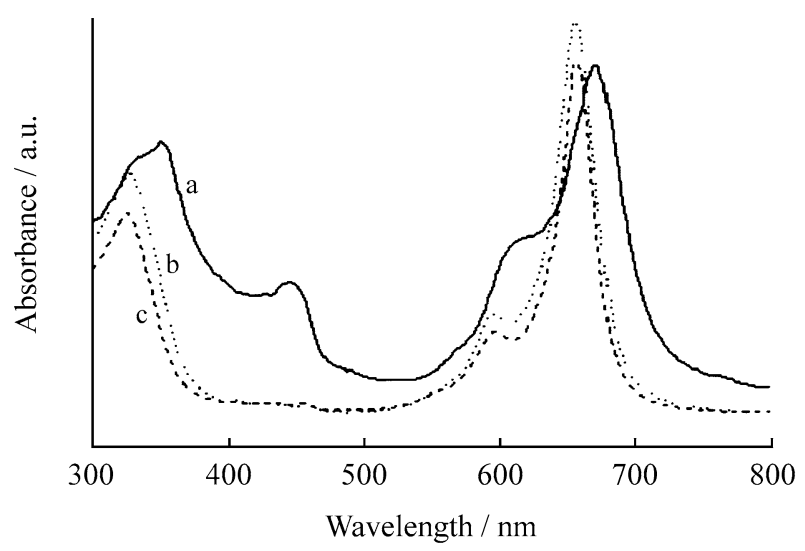

Figure 2. Electronic absorption spectra of: (a) $\mathrm{SiIm} / \mathrm{CoPc}$ immersed in $\mathrm{CCl}_{4}$ (b) CoPc dimethylsulphoxide solution $\left(2 \times 10^{-5} \mathrm{~mol} \mathrm{~L}^{-1}\right)$ and (c) CoPc dimethylformammide solution $\left(2 \times 10^{-5} \mathrm{~mol} \mathrm{~L}^{-1}\right)$. 
served because the refractive index of silica gel matrix $\left(\eta_{D}\right.$ $=1.45845$ ) is nearly the same of that of carbon tetrachloride $\left(\eta_{D}=1.4595\right)^{22}$. Figure 2a is compared with the spectrum of CoPc dissolved in dimethylsulphoxide (Fig. 2b) and dimethylformamide (Fig. 2c). The maximum of the absorption band peaks of the complex in solution phase, named B and Q bands, are observed at 326 and $657 \mathrm{~nm}$, respectively. For SiIm/CoPc the maximum of these absorption band peaks are observed at 354 and $672 \mathrm{~nm}$. It is known that for metal phthalocyanine axially coordinated with a ligand, the $\pi$ interaction between the metal $\mathrm{d}_{\mathrm{xz}}$ and $\mathrm{d}_{\mathrm{yz}}$ orbitals with the ring $\mathrm{e}_{\mathrm{g}}\left(\pi^{*}\right)$ orbitals, or LUMO, is enhanced ${ }^{23}$. The decrease of the energy gap between these two levels upon axial interaction in comparison with that in the free complex, decreases the energy transitions, $\mathrm{a}_{1 \mathrm{u}}(\pi) \rightarrow \mathrm{e}_{\mathrm{g}}\left(\pi^{*}\right)$ (Q bands) and $\mathrm{a}_{2 \mathrm{u}}(\pi), \mathrm{b}_{2 \mathrm{u}}(\pi) \rightarrow \mathrm{e}_{\mathrm{g}}\left(\pi^{*}\right)$ (B bands). Therefore, in the present case the shift of the Q and B bands to lower wavelength regions is attributed to the imidazole molecule bonding to the metal atom in $\mathrm{CoPc}^{24}$.

\section{Electrochemical studies}

\section{Pulse differential voltammetry of SiIm/CoPc}

Figure 3 shows the pulse differential voltammetry curve for $\mathrm{SiIm} / \mathrm{CoPc}$ obtained in $0.1 \mathrm{~mol} \mathrm{~L}^{-1} \mathrm{NaCl}$ supporting electrolyte solution and $\mathrm{pH}$ 6. The anodic sweeping show two peaks corresponding to the following oxidation processes: $\mathrm{Co}(\mathrm{I}) \rightarrow \mathrm{Co}(\mathrm{II})=-0.55 \mathrm{~V}$ and $\mathrm{Co}(\mathrm{II}) \rightarrow \mathrm{Co}(\mathrm{III})=$ $0.70 \mathrm{~V}$

These oxidation potentials are very similar to those observed for cobalt(II) tetrasulfophthalocyanine com-

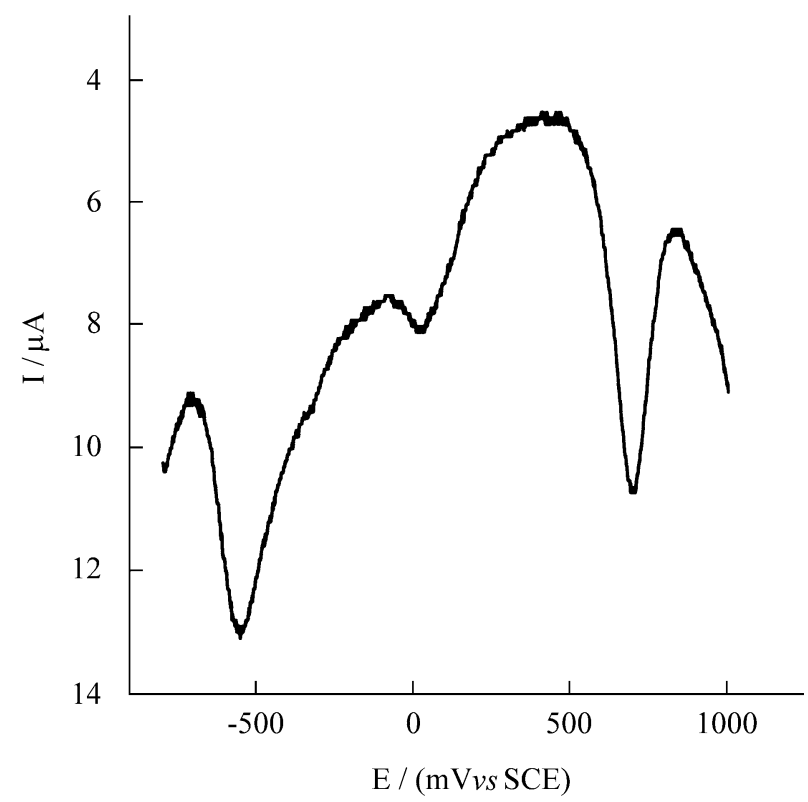

Figure 3. Pulse differential voltammetry for $\mathrm{Silm} / \mathrm{CoPc}$ carbon paste electrode immersed in $0.1 \mathrm{~mol} \mathrm{~L}^{-1} \mathrm{NaCl}$ solution at $\mathrm{pH} 6$.

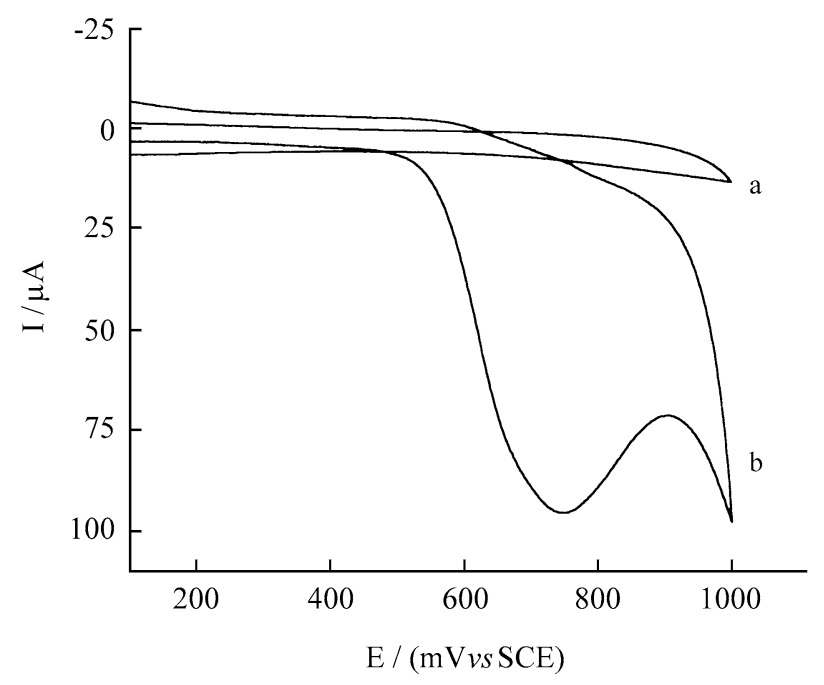

Figure 4. Cyclic voltammograms fo $\mathrm{SiIm} / \mathrm{CoPc}$ in $0.5 \mathrm{~mol} \mathrm{~L}^{-1} \mathrm{NaCl}$ solution, $\mathrm{v}=20 \mathrm{mV} \mathrm{s}^{-1}$ at pH 3.5. (a) in absence of oxalic acid (b) $\left[\mathrm{HC}_{2} \mathrm{O}_{4}^{-}\right]$ $=2.5 \times 10^{-3} \mathrm{~mol} \mathrm{~L}^{-1}$.

plex $^{12}$. The other anodic peak at $0.023 \mathrm{~V}$ with lower current intensity was not assigned and its origin is not explained.

\section{Electroxidation of oxalic acid}

In order to study the capability for the immobilized $\mathrm{Co}(\mathrm{II})$ phthalocyanine to mediate oxidative processes, the oxalic acid oxidation was chosen. The cyclic voltammetry technique was used to carry out such study.

Figure 4 shows the cyclic voltammograms obtained for $\mathrm{SiIm} / \mathrm{CoPc}$ at $\mathrm{pH} 3.6$ in presence (Fig. 4b) and absence of oxalic acid (Fig. 4a). No current peak is observed when the potential is swept between 0 and $1 \mathrm{~V}$ and in the presence of oxalic acid $2.5 \times 10^{-3} \mathrm{~mol} \mathrm{~L}^{-1}$ an anodic current peak is observed.

Changing the scan rates, $\mathrm{v}$, and plotting $\mathrm{I}_{\mathrm{pa}}$ against $\mathrm{v}^{1 / 2}$, a linear correlation was obtained (Fig. 5). This is an indication that the oxidation process is a diffusion controlled process.

The electroxidation of the oxalic acid at the solid-solution interface can be described by the following reactions:

$$
\begin{aligned}
& \left.2\left[\mathrm{Co}{ }^{\mathrm{II}} \mathrm{Pc}\right] \rightleftharpoons 2\left[\mathrm{Co}^{\mathrm{III}} \mathrm{Pc}\right]^{+}+2 \mathrm{e}^{-} \text {(electrode }\right) \\
& \mathrm{H}_{2} \mathrm{C}_{2} \mathrm{O}_{4}+2\left[\mathrm{Co}^{\mathrm{III}} \mathrm{Pc}\right]^{+} \longrightarrow 2\left[\mathrm{Co}{ }^{\mathrm{II}} \mathrm{Pc}\right]+2 \mathrm{CO}_{2}+2 \mathrm{H}^{+} \\
& \text {(electrode-solution interface) }
\end{aligned}
$$

The oxalic acid oxidation is strongly influenced by the solution $\mathrm{pH}$ since the dissociation constants are $\mathrm{pK}_{1}=1.46$ and $\mathrm{pK}_{2}=4.4^{25}$, for the first and second dissociation constants, respectively. The response of the electrode to oxalic acid concentrations was studied at pHs 3.5, 6 and 7 .

Figure 6 shows the plot of $\mathrm{I}_{\mathrm{pa}}$ against $\left[\mathrm{H}_{2} \mathrm{C}_{2} \mathrm{O}_{4}\right]$ in the concentration range from $6.5 \times 10^{-4}$ to $3.2 \times 10^{-3} \mathrm{~mol} \mathrm{~L}^{-1}$, in $0.5 \mathrm{~mol} \mathrm{~L}^{-1} \mathrm{NaCl}$ solution and $\mathrm{v}=20 \mathrm{mV} \mathrm{s}^{-1}$. To keep the $\mathrm{pH}$ constant, the buffers acetic acid/acetate $(\mathrm{pH} 3.5)$, biphthalate (pH 6.0) and TRIS (pH 7.0) were used. 


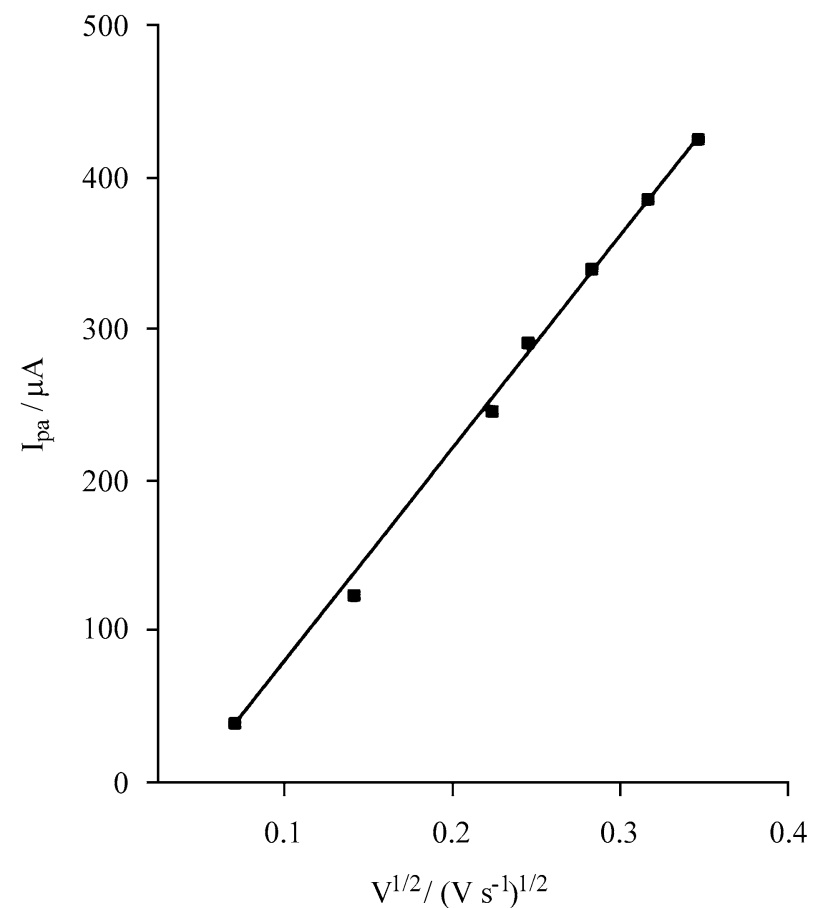

Figure 5. Plot of $\mathrm{Ipa}_{\text {against }} \mathrm{v}^{1 / 2}$ for $\left[\mathrm{HC}_{2} \mathrm{O}_{4}{ }^{-}\right]=2.5 \times 10^{-3} \mathrm{~mol} \mathrm{~L}^{-1}$ in 0.5 $\mathrm{mol} \mathrm{L}{ }^{-1} \mathrm{NaCl}$ solution, $\mathrm{v}=20 \mathrm{mV} \mathrm{s}^{-1}$ and $\mathrm{pH} 3.5$.

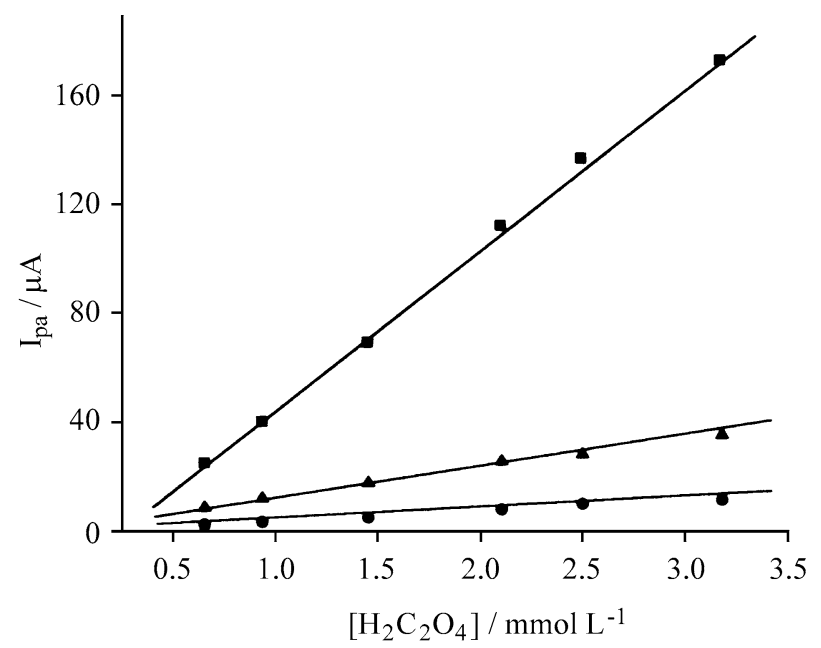

Figure 6. Plot of $\mathrm{I}_{\mathrm{pa}}$ against oxalic acid concentration in $0.5 \mathrm{~mol} \mathrm{~L}^{-1}$

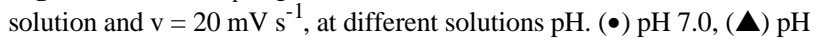

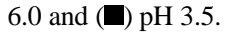

In every case a linear correlation between $\mathrm{I}_{\mathrm{pa}}$ and $\left[\mathrm{H}_{2} \mathrm{C}_{2} \mathrm{O}_{4}\right]$ was obtained and the angular coefficients were 59.3, 3.4 and 10.2 for $\mathrm{pHs} 3.5,6.0$ and 7.0, respectively. A higher sensitivity is achieved for $\mathrm{pH} 3.5$ where the $\mathrm{HC}_{2} \mathrm{O}_{4}{ }^{-}$ species is the predominant one.

\section{Chemical stability of the electrode}

The stability of the electrode was studied cycling the potential in a $2.5 \times 10^{-3}$ mol L-1 $\mathrm{HC}_{2} \mathrm{O}_{4}^{-}$solution, $0.5 \mathrm{~mol}$ $\mathrm{L}^{-1} \mathrm{NaCl}$ supporting electrolyte solution and scan rate of

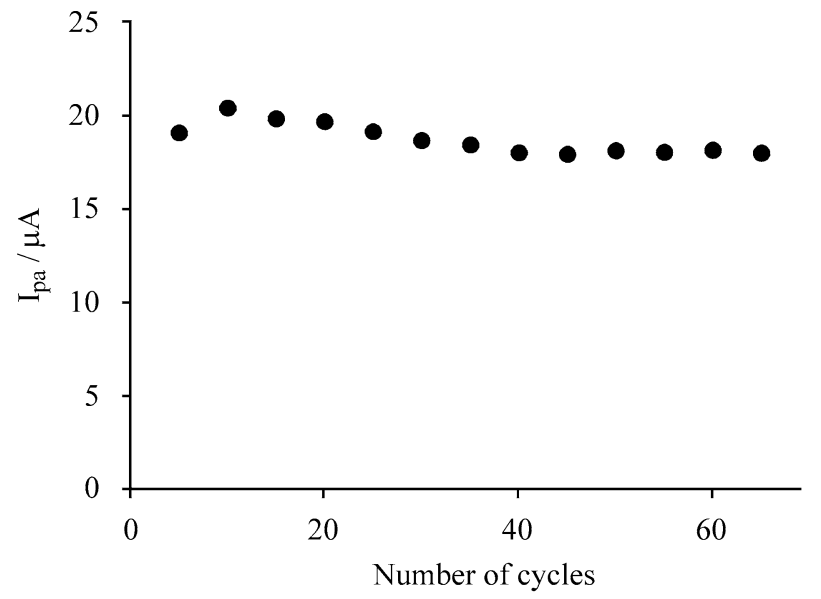

Figure 7. Chemical stability of the $\mathrm{SiIm} / \mathrm{CoPc}$ electrode under various redox cycles. $\left[\mathrm{HC}_{2} \mathrm{O}_{4}{ }^{-}\right]=2.5 \times 10^{-3} \mathrm{~mol} \mathrm{~L}^{-1}$ in $0.5 \mathrm{~mol} \mathrm{~L}^{-1} \mathrm{NaCl}$ solution, $\mathrm{v}=20 \mathrm{mV} \mathrm{s}^{-1}$ and $\mathrm{pH} 3.5$.

$20 \mathrm{mV} \mathrm{s}^{-1}$. The $\mathrm{I}_{\mathrm{pa}}$ current plotted against the number of cycles (Fig. 7) showed that it did not decrease after 65 cycles, indicating that the electroactive species was not leached from the electrode surface.

\section{Conclusions}

The CoPc complex on 3-n-propylimidazole groups grafted on $\mathrm{SiO}_{2}$ surface efficiently electrocatalyzed the oxalic acid oxidation on a carbon paste electrode surface made of this material. Intermolecular interactions of the complex species which can normally interfere in the redox process practically were not observed in the present case because of the low average surface density of the complex species $\left(4.7 \times 10^{-13} \mathrm{~mol} \mathrm{~cm}{ }^{-2}\right)$ prepared. A linear response of the electrode for oxalic acid concentration, between 6.5 x $10^{-4}$ and $3.2 \times 10^{-3} \mathrm{~mol} \mathrm{~L}^{-1}$, associated with its high chemical stability make the covalently immobilized Cophthalocyanine complex material very attractive in preparing new class of chemical sensors.

\section{Acknowledgments}

YG id indebted to FAPESP and Finep/PRONEX for financial support and STF to CNPq for a fellowship

\section{References}

1.Zagal, J. H. Coord Chem Rev. 1992, 119, 89.

2.Zecevic, S.; Glavaski, B. S.; Yeager, E.; Lever, A.B.P.; Minor, P.C. J. Electroanal. Chem. 1985, 196, 339.

3. Lever, A.B.P. Adv. Inorg. Chem. Radiochem. 1965, 7 , 27.

4. Lisichkin, G.V.; Kudryavtsev, G.V.; Nesterenko, P.N. J. Anal. Chem. USSR 1983, 38, 1288.

5. Kubota, L.T.; Gushikem, Y.; Perez, J.; Tanaka, A.A. Langmuir 1995, 11, 1009. 
6.Li, J.Z.; Wu, X.C.; Yuan, R.; Lin, H. G.; Yu, R.Q. Analyst 1994, 119, 1363.

7.Wang, J.; Golden, T.; Li, R. Anal. Chem. 1988, 60, 1642.

8. Santos, L.M.; Baldwin, R.P. Anal. Chem. 1986, 58, 848.

9. Napier, A.; Hart, J.P. Electroanalysis 1996, 8, 1006.

10. Wring, S.A.; Hart, J.P.; Birch, B. J. Anal. Chim. Acta 1990, 229, 63.

11. Skaládal, P. Anal. Chim. Acta 1991, 252, 11.

12.Huang, X.; Kok, W.T. Anal. Chim. Acta 1993, 273, 245.

13. Iamamoto, Y.; Ciuffi, K.J.; Sacco, H.C.; Iwamoto, L.S.; Nascimento, O.R.; Prado, C.M.C. J. Mol. Catal. A 1997, 116, 405.

14. Leal, O.; Anderson, D.L.; Bowman, R.G.; Basolo, F.; Burwell, R.L.J. J. Am. Chem. Soc. 1975, 97, 5125.

15.Hoffmann, M.R.; Hong, A.P. Sci. Total Environ. 1987, 64, 99.
16. Hong, A.P.; Boyce, S.D.; Hoffmann, M.R. Environ. Sci. Technol. 1989, 23, 533.

17. Ouédraogo, G.V.; More, C.; Richard, Y.; Benlian, D. Inorg. Chem. 1981, 20, 4387.

18. Blomquist, J.; Helgeson, U.; Moberg, L.C. Spectrosc. Lett. 1985, 18, 575.

19. Jones, J.G.; Twigg, M.V.; Inorg. Chem. 1969, 8, 2120.

20. Folkesson, B.; Johansson, L.Y.; Larsson, R.; Yom Tov, B.; J. Appl. Electrochem. 1983, 13, 355.

21. Kobayashi, N.; Koshiyama, M.; Funayama, K.; Osa, T.; Shirai, H.; Hanabusa, K. J. Chem. Soc. Chem. Commun. 1983, 913.

22. Filipov, A.P.; Karpenko, G.A. Theor. Exp. Chem. 1978, 14, 333.

23. Fierro, C.; Anderson, A.B.; Scherson, D.A. J. Phys. Chem. 1988, 92, 6902.

24. Nyokong, T. Polyhedron 1994, 13, 215.

25. Dryhurst, G.; McAllister, D.L.Anal. Chim. Acta 1974, $72,209$.

Received: October 21, 1998

FAPESP helped in meeting the publication costs of this article 